flying boats ; Simms Gold Medal to Dr. H. J. Gough, for his paper "New Light on the Strength of Materials afforded by Modern Physics" ; Simms Gold Medal to W. A. Wood, for his paper on "New Light on the Strength of Materials afforded by Modern Physics"; Taylor Gold Medal to Dr. G. P. Douglas, for his paper on "Cooling Problems with particular Reference to the work of the $24 \mathrm{ft}$. R.A.E. Tunnel" ; Edward Busk Memorial Prize to Mr. G. H. Dowty, for his paper on "Retractable Undercarriages"; Pilcher Memorial Prize to $\mathbf{H}$. Leaderman, for his paper on "The Fundamentals of Boundary Layer Theory with Some Applications to Aircraft".

\section{Current Sunspots}

AFTER some weeks of only moderate solar activity compared with the great activity shown from about last November until January, the recent appearance of an extensive active area of the sun may be noted. There are three chief groups of spots, one of them showing a rapid development from April 19, when the total area was only about 50 millionths of the sun's hemisphere, to April 22 when the area had increased to 1,750 millionths. Particulars of the groups of spots are as follows :

\begin{tabular}{cccc} 
Date on Disk & Central Meridian & \multicolumn{2}{c}{ Maximum } \\
Passage & Latitude & Area \\
April 15-28 & April $22 \cdot 4$ & $10^{\circ} \mathrm{S}$. & 650 \\
" $16-29$ & $" 23 \cdot 2$ & $25^{\circ} \mathrm{N}$. & 900 \\
" $18-30$ & $" 24 \cdot 6$ & $19^{\circ} \mathrm{N}$. & 1750
\end{tabular}

Bright hydrogen eruptions were observed in association with the largest group on April 21 between $11^{\mathrm{h}}$ and $12^{\mathrm{h}}$ and $15^{\mathrm{h}}-16^{\mathrm{h}}$ U.T., whilst a series of small but very bright eruptions occurred on April 23. Another bright eruption, more extensive than any of these, was observed at Greenwich on April 25 between $8 \frac{1 \mathrm{~h}}{2}$ and $11 \frac{1}{2} \mathrm{~h}$. Two magnetic storms were recorded at Greenwich beginning on April 24 at $12^{\mathrm{h}} 0^{\mathrm{m}}$ and on April 25 at $15^{\mathrm{h}} 45^{\mathrm{m}}$. For the first storm, the ranges in declination, horizontal force and vertical force were $46^{\prime}, 275 \gamma$ and $145 \gamma$ respectively, and for the second (up to April $2610^{\mathrm{h}}$ ) $30^{\prime}, 310 \gamma$ and $105 \gamma$ respectively. The second of these storms would seem to be related to the display of aurora reported by Mr. E. L. Hawke in The Times of April 27 as seen on April 25 from the Chiltern Hills.

\section{The Night Sky in May}

DURING the month, the duration of night decreases in the latitude of London by nearly $1 \frac{1}{2}$ hours. The moon is new on May 10 at $13 \cdot 3^{\mathrm{h}}$ and full on May 25 at $7 \cdot 6^{\mathrm{h}}$, when a penumbral eclipse takes place. The greatest altitude of the moon at meridian passage $\left(61 \cdot 2^{\circ}\right)$ is on May 12, and the least altitude, $15 \cdot 9^{\circ}$, on May 26. Venus is a morning star rising just ovor an hour before the sun; on and about May 24 the planet is at its greatest brilliancy (magnitude $-4 \cdot 2$ ). Conjunction with the moon occurs on May 8 at $15^{\mathrm{h}}$. On May 11 at $11^{\mathrm{h}}$, Mercury is in inferior conjunction with the sun, and a partial transit (invisible from Great Britain) of the sun's disk occurs the same day between $8 \frac{1}{2} \mathrm{~h}$ and $9 \frac{1}{2} \mathrm{~h}$. The planet Mars is conspicuous low down in the night sky and souths about midnight in the middle of the month. On May 19, Mars is in opposition, and nearest to the earth on May 28, when the apparent diameter of the planet is $18 \mathbf{1}^{\prime \prime}$. On May 24 at $18^{\mathrm{h}}$, there is a conjunction with the moon, Mars being $0.6^{\circ}$ northwards. Jupiter is a morning star of about mag. $-2 \cdot 0$ in Sagittarius. Saturn rises in the dawn and can only be located with difficulty. About May 5, the maximum of the $\eta$ Aquarid meteors occurs, the radiant being at R.A. $22^{\mathrm{h}} 32^{\mathrm{m}}$ : Dec. $-2^{\circ}$, and on May 24 that of the Herculids, the radiant of which is at R.A. $16^{\mathrm{h}} 36^{\mathrm{m}}$ and Dec. $+30^{\circ}$. Approximate positions for Comet Whipple (1937b) are given by Möller's ephemeris in I.A.U. Circular No. 653, as follows :

\begin{tabular}{crrrr} 
Date & R.A. & \multicolumn{2}{c}{ Dec } \\
May & 3 & $14^{\mathrm{h}} 21 \cdot 9 \mathrm{~m}$ & $+60^{\circ}$ & $28^{\prime}$ \\
" & 7 & $22 \cdot 7$ & 60 & 18 \\
" 11 & $23 \cdot 7$ & 59 & 58 \\
" 15 & $25 \cdot 0$ & 59 & 29 \\
" 19 & $26 \cdot 5$ & 58 & 49
\end{tabular}

All times in this note are in U.T. ; add $\mathrm{I}^{\mathrm{h}}$ to convert to Summer Time.

\section{Announcements}

The proceeds of the Daniel Pidgeon Fund for 1937 of the Geological Society of London have been awarded in equal proportions to Dr. G. F. Claringbull, who proposes to investigate the geology and petrology of the Ross of Mull granite, and Mr. F. W. Cope, who proposes to map the central region of the Derbyshire dome, and to correlate the Lower Carboniferous rocks of the area with those of North Wales, Westmorland, and the type section of the Avonian.

Prof. George R. Murray, emeritus professor of medicine in the University of Manchester, has been made a member of a Departmental Committee appointed by the Home Secretary to consider the question of compensation for card-room and other workers in the cotton industry disabled by respiratory diseases.

Dr. John B. Grant, of the Rockefeller Foundation, was recently decorated by the National Government of China on the occasion of the New Year with the Fifth Order of Beautiful Jade for his meritorious services in China. This order was awarded especially for his pioneering and developing public health work and in promoting medical education in China.

A Royal Rumanian Society of Genetics and Eugenics has recently been founded at Bukarest under the presidency of Prof. G. Marinesco.

WE have received from the Association of British Chemical Manufacturers, 166 Piccadilly, London, W.I, a copy of the second edition of the "Index to Acts of Parliament and Statutory Rules and Orders affecting the Chemical Industry", which comprises supplements bringing the work up to date to December 31,1936 . Copies may be obtained from the Association at the price of $2 s$. 6d. post paid, remittance accompanying the order. 